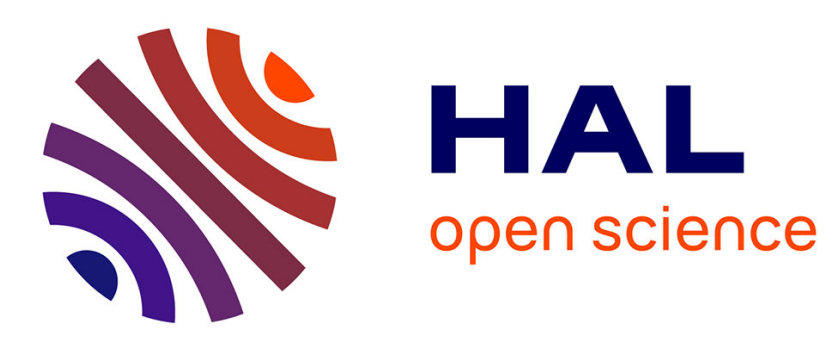

\title{
The parent tetrathiafulvalene-terpyridine dyad: synthesis and metal binding properties
}

Esmah Belhadj, Abdelkrim El-Ghayoury, Miloud Mazari, Marc Sallé

\section{To cite this version:}

Esmah Belhadj, Abdelkrim El-Ghayoury, Miloud Mazari, Marc Sallé. The parent tetrathiafulvaleneterpyridine dyad: synthesis and metal binding properties. Tetrahedron Letters, 2013, 54 (24), pp.30513054. 10.1016/j.tetlet.2013.03.102 . hal-03344543

\section{HAL Id: hal-03344543 \\ https://univ-angers.hal.science/hal-03344543}

Submitted on 15 Sep 2021

HAL is a multi-disciplinary open access archive for the deposit and dissemination of scientific research documents, whether they are published or not. The documents may come from teaching and research institutions in France or abroad, or from public or private research centers.
L'archive ouverte pluridisciplinaire HAL, est destinée au dépôt et à la diffusion de documents scientifiques de niveau recherche, publiés ou non, émanant des établissements d'enseignement et de recherche français ou étrangers, des laboratoires publics ou privés. 


\title{
The parent tetrathiafulvalene-terpyridine dyad: synthesis and metal binding properties
}

\author{
Esmah Belhadj ${ }^{\mathrm{a}, \mathrm{b}}$, Abdelkrim El-Ghayoury ${ }^{\mathrm{a}, *}$, Miloud Mazari ${ }^{\mathrm{b}}$, Marc Sallé ${ }^{\mathrm{a}, *}$ \\ a LUNAM Université, Université d'Angers, CNRS UMR 6200, Laboratoire MOLTECH-Anjou, 2 bd Lavoisier, 49045 Angers Cedex, France \\ ${ }^{\mathrm{b}}$ Laboratoire de Synthèse Organique Appliquée d'Oran, Université d'Oran Es-Sénia, Algeria
}

\section{A R T I C L E I N F O}

Article history:

Received 12 February 2013

Revised 21 March 2013

Accepted 22 March 2013

Available online 3 April 2013

\section{Keywords:}

Tetrathiafulvalene

Terpyridine

Metal complex

Electronic absorption

Cyclic voltammetry

\begin{abstract}
A B S T R A C T
The still unknown parent tetrathiafulvalene-terpyridine- ligand $\mathbf{5}$ (namely TTF-terpy), was synthesized through a straightforward strategy. The dyad exhibits an intramolecular charge transfer (ICT) which was evidenced by UV-vis electronic absorption. Complexation of various transition metal cations by this redox-active ligand was studied by UV-vis absorption spectroscopy as well as by cyclic voltammetry titration studies, supporting the dual functional character of this system. In addition, these results demonstrate that ligand $\mathbf{5}$ is a suitable building block for the preparation of electroactive neutral as well as charged metal complexes.
\end{abstract}

(c) 2013 Elsevier Ltd. All rights reserved.
Tetrathiafulvalene (TTF) and its derivatives have been the subject of considerable attention, in particular for their ability to reach molecular conductors and superconductors at the solid state. ${ }^{1}$ This behavior is mainly supported by their strong electron donating ability which results in two sequential and reversible oxidation processes, affording stable cation radical $\left(\mathrm{TTF}^{\circ+}\right)$ and dication $\left(\mathrm{TTF}^{2+}\right)$ species. $^{2}$ In addition, they have also found use as redox switches in more recent molecular and supramolecular architectures. $^{3}$ In particular, many efforts have been devoted to the association of a binding unit to the redox-active TTF moiety, either to produce TTF-based redox-responsive receptors for guest sensing applications in solution, ${ }^{3}$ or to reach multifunctional molecular materials that can exhibit, in the solid state, an interplay between two or more physical properties such as magnetism and electrical conductivity. ${ }^{4}$ On this ground, only few of these TTF-based ligands incorporate an oligopyridine-based coordinating unit. ${ }^{5}$ Falling into this category, pyridines, ${ }^{6}$ bipyridines, ${ }^{6 c, 7}$ 1,10-phenanthroline, ${ }^{8}$ Schiff bases, ${ }^{9}$ and dipyridylamines ${ }^{10}$ TTF-based ligands have been synthesized. Surprisingly, though the $2,2^{\prime} ; 6^{\prime}, 2^{\prime \prime}$-terpyridine unit is a well-established building block for allowing a strong and topologically predictable binding to essentially all metal ions, ${ }^{11}$ only one example of TTF $/ 2,2^{\prime} ; 6^{\prime}, 2^{\prime \prime}$-terpyridine assembly has been reported so far, with no investigation of any metal complexation. ${ }^{12}$ Very recently we have reported two new TTF $/ 2,2^{\prime} ; 6^{\prime}, 2^{\prime \prime}$-terpyridine

* Corresponding authors. Tel.: +33 2417354 92; fax: +33 241735405 (A.El-.G.); tel.: +33 2417354 39; fax: +332 41735405 (M.S.).

E-mail addresses: abdelkrim.elghayoury@univ-angers.fr (A. El-Ghayoury), marc. salle@univ-angers.fr (M. Sallé). ligands which incorporate an amide linker between the two subunits. ${ }^{13}$ Herein we report on the straightforward synthesis and the study of complexation ability of the pristine TTF-terpy ligand $\mathbf{5}$, for which the two units are directly connected through one carbon-carbon covalent bond.

The synthesis protocol of the TTF-terpy ligand $\mathbf{5}$ involves the progressive construction of the terpy moiety ${ }^{11,14}$ on the periphery of the TTF unit (scheme 1). The starting formyltetrathiafulvalene $\mathbf{1}$ was prepared as previously described ${ }^{15}$ in $56 \%$ yield by lithiation and formylation, at low temperature, of the commercially available tetrathiafulvalene. The formyl derivative $\mathbf{1}$ was then reacted through an aldol condensation, with 2-acetylpyridine $\mathbf{2}$ in the presence of sodium methanolate to afford the TTF-enone intermediate 3. ${ }^{16}$

Compound 3 was subjected to a Michael addition with the pyridylacetylpyridinium iodide salt $\mathbf{4}$ which was prepared from 2-acetyl pyridine [Scheme 2, reaction (iii)]. ${ }^{17}$ The ring closure reaction [reaction (iv)] was led in the presence of ammonium acetate affording the desired $4^{\prime}$-tetrathiafulvalene- $2,2^{\prime} ; 6^{\prime}, 2^{\prime \prime}$-terpyridine $5^{18}$

The electronic absorption spectrum of TTF-terpy ligand $\mathbf{5}$ was recorded in a dichloromethane/acetonitrile solution (Supplementary Figure S1). This ligand exhibits two strong electronic absorption bands at $\lambda=283 \mathrm{~nm}$ and $318 \mathrm{~nm}$ which are assigned to the ligand centered $\pi \rightarrow \pi^{*}$ and $n \rightarrow \pi^{*}$ transitions of both the TTF ring and the aromatic terpyridine ring. The broad band observed in the visible region around $\lambda_{\max }=450 \mathrm{~nm}$ is characteristic of the intramolecular charge transfer transition (ICT) from the 
<smiles>C1=CSC(=C2SC=CS2)S1</smiles>

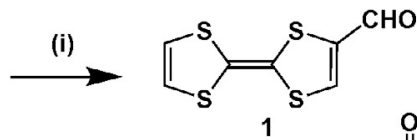

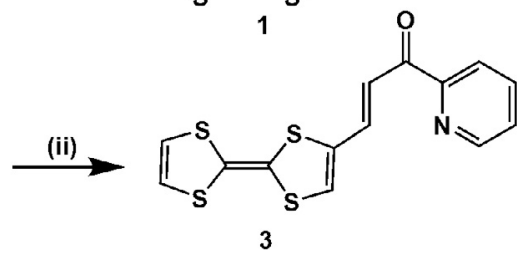

Scheme 1. Synthesis scheme of TTF-enone 3. Reagents and conditions: (i) 1) LDA, $\mathrm{Et}_{2} \mathrm{O},-75^{\circ} \mathrm{C}, \mathrm{Ar}, 40 \mathrm{~min} .2$ ) $\mathrm{N}$-methylformanilide, $-75^{\circ} \mathrm{C}, \mathrm{Ar}, 40 \mathrm{~min} .56 \%$; (ii) $\mathrm{THF}$, $\mathrm{CH}_{3} \mathrm{ONa}, 30{ }^{\circ} \mathrm{C}, 12 \mathrm{~h}, 30 \%$.

highest occupied molecular orbital (HOMO) of TTF to the lowest unoccupied molecular orbital (LUMO) of the electron-accepting terpyridyl unit. ${ }^{19}$ These values are similar to the values obtained for the previously described EDT-TTF-CONH-terpyridine ligand. ${ }^{13}$

Theoretical calculations based on density functional theory (DFT) methods have been performed with the GAUSSIAN 09 program. ${ }^{20}$ Becke's three parameter gradient-corrected functional (B3LYP) with 6-31G (d,p) basis in vacuo was used for full geometry optimization and to compute the electronic structure at the minima found. The resulting frontier molecular orbitals are given in Figure 1. The optimized geometry of ligand $\mathbf{5}$ reveals a coplanar conformation for the three pyridine cycles and a significant bending for the TTF fragment that is typical of the TTF-based molecules in the neutral state. The rotation angle around the TTF-terpy bond is of $24^{\circ}$, which illustrates a moderate distortion between the two units. The electron density of the HOMO orbital is located on the TTF fragment, while the LUMO is essentially distributed over the central pyridine cycle and the dithiole ensemble. The HOMO value $\left(E_{\mathrm{HOMO}}=-4.616 \mathrm{eV}\right.$ ) confirms that the high $\pi$-donating ability of the TTF framework is maintained in the ligand. The calculated band gap $\left(E_{\mathrm{g}}=2.94 \mathrm{eV}\right)$ between the HOMO $\left(E_{\mathrm{HOMO}}=-4.616 \mathrm{eV}\right)$ and the LUMO $\left(E_{\mathrm{LUMO}}=-1.677 \mathrm{eV}\right)$ is in reasonable accordance with the experimental optical band gap $E_{\mathrm{g}} \sim 2.74$ evaluated from the $\lambda_{\max }$ of the ICT band, this difference being assigned to the solvent effects, which are neglected in calculations.

The $2,2^{\prime} ; 6^{\prime}, 2^{\prime \prime}$-terpyridine derivatives are known to form stable complexes with most transition metal ions. ${ }^{11}$ In particular, because of their $\pi$-accepting character, they behave as chelating ligands for low oxidation states transition metals such as $\mathrm{Fe}^{2+}, \mathrm{Co}^{2+}, \mathrm{Cu}^{2+}, \mathrm{Zn}^{2+}$, $\mathrm{Cd}^{2+}, \mathrm{Ru}^{2+}, \mathrm{Os}^{2+}, \ldots$ which therefore allows to generate and to isolate the corresponding $\left.[\mathrm{M} \text { (terpyridine })_{2}\right]^{2+}$ complexes.

Preliminary metal binding studies were undertaken from the pristine TTF-terpy ligand 5 in the presence of $\mathrm{Ni}(\mathrm{II}), \mathrm{Zn}(\mathrm{II}), \mathrm{Cd}(\mathrm{II})$, and $\mathrm{Fe}(\mathrm{II})$ as illustrative examples. A UV-visible titration was performed by adding increasing amounts of a nickel perchlorate solution into a $\mathrm{CH}_{2} \mathrm{Cl}_{2} / \mathrm{CH}_{3} \mathrm{CN}$ solution of ligand $\mathbf{5}$ (Fig. 2). A progressive
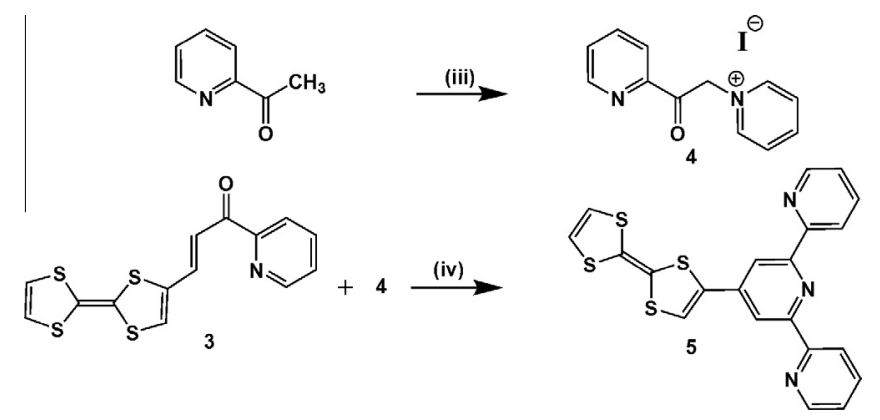

Scheme 2. Synthesis scheme of TTF-Terpy 5. Reagents and conditions: (iii) Pyridine, $\mathrm{I}_{2}$, reflux, 1 h, $95 \%$; (iv) $\mathrm{NH}_{4} \mathrm{OAc}, \mathrm{EtOH}, 20 \%$.

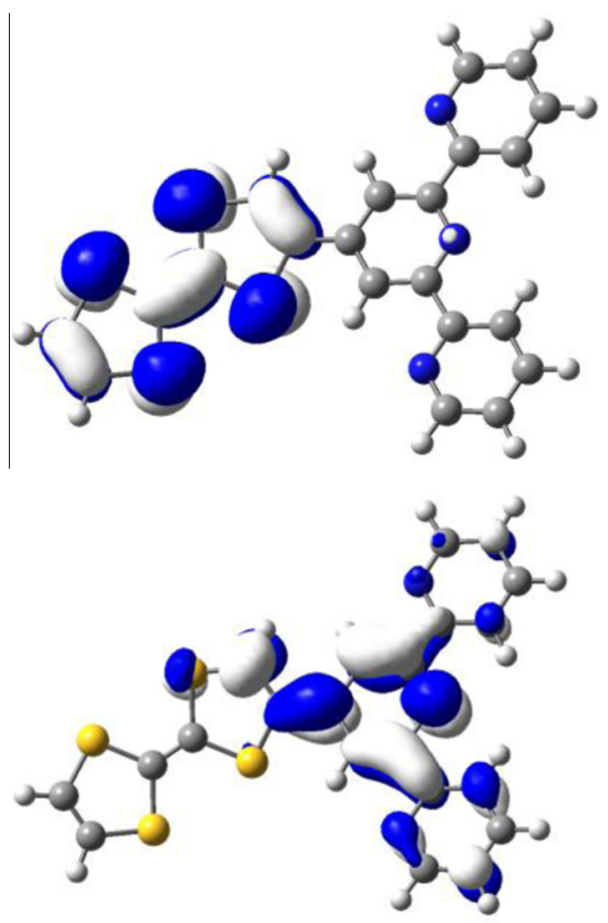

Figure 1. Frontier molecular orbitals of ligand 5. Top (HOMO), bottom (LUMO).

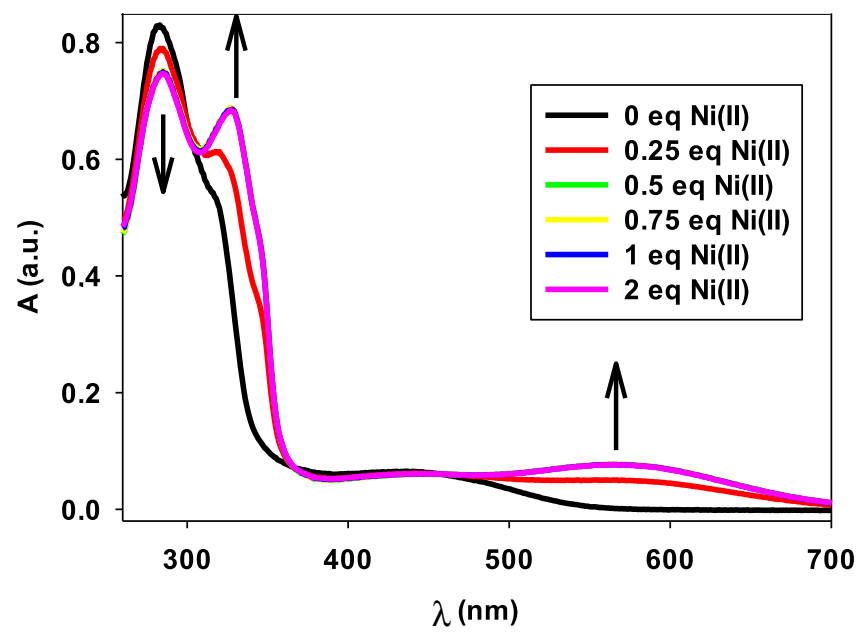

Figure 2. UV-vis titration of ligand $5\left(C=1.2510^{-5} \mathrm{M}\right)$ by $\mathrm{Ni}\left(\mathrm{ClO}_{4}\right)_{2}$, in $\mathrm{DCM} / \mathrm{ACN}$ $(1 / 1, v / v)$ (curves from 0.5 equiv (green) to 2 equiv (pink) are exactly identical).

decreasing of the band located at $283 \mathrm{~nm}$ and the concomitant appearance of a new band around $318 \mathrm{~nm}$ were observed. The latter new absorption band corresponds to a ligand centered (LC, $\pi \rightarrow \pi^{*}$ and $\mathrm{n} \rightarrow \pi^{*}$ ) transitions that appears upon formation of a metal complex and is likely due to the conformational change (all trans to all cis) of the chelating terpyridine moiety upon complexation. ${ }^{11}$ It appears clear from the titration, that no additional absorption change is observed upon introduction of more than 0.5 equiv of $\mathrm{M}\left(\mathrm{ClO}_{4}\right)_{2}$ (yellow to pink curves) as expected for the formation of 2:1 complexes. Note that the ICT transition is red shifted by more than $100 \mathrm{~nm}$ in the metal complex related to free 5, indicating a significant effect of metal complexation. This effect appears more important than with the previously described TTFCONH-terpy ligand. ${ }^{13}$ Such observation is likely to be due to the close proximity between the directly connected TTF and 
terpyridine units in $\mathbf{5}$, as well as to the good $\pi$-delocalization shown by calculations above. The same behavior is observed upon titrations of zinc perchlorate (Supplementary Figure S2) and cadmium perchlorate (Supplementary Figure S3).

In the case of $\mathrm{Fe}^{2+}$, the high intensity of the absorption band in the visible region suggests a superimposition of both the red shifted ICT band and the Metal to Ligand Charge Transfer (MLCT) ${ }^{21}$ band which indicate the formation of $\left[\mathrm{Fe}(\mathbf{5})_{2}\right]^{2+}$ (Supplementary Figure S4).

The electrochemical behavior of ligand $\mathbf{5}$ was investigated by cyclic voltammetry. This measurement shows the usual two reversible one-electron oxidations of the TTF unit, which correspond to the successive formation of a radical cation at $+0.005 \mathrm{~V}$ and a dication at $+0.430 \mathrm{~V}$ ( $\mathrm{vs} \mathrm{Fc}^{+} / \mathrm{Fc}$ ). These oxidation potentials are slightly positively shifted when compared to pristine TTF $\left(-0.035 \mathrm{~V}\right.$ and $0.265 \mathrm{~V} \mathrm{vs} \mathrm{Fc}^{+} / \mathrm{Fc}$ ), which is assigned to the presence of the electron-deficient terpyridine moiety.

Treatment of an electrolytic solution of ligand $\mathbf{5}$ with an increasing amount of nickel perchlorate in a $\mathrm{CH}_{2} \mathrm{Cl}_{2} / \mathrm{CH}_{3} \mathrm{CN}$ mixture causes an anodic shift $(+60 \mathrm{mV})$ of the first oxidation potential (Fig. 3). This behavior is assigned to the increased accepting character of the terpyridine fragment upon complexation of a metal cation. ${ }^{22}$ In the case of $\mathrm{Fe}^{2+}$, in addition to the changes observed above, a new band is observed at $+0.576 \mathrm{~V}$ which is assigned to the oxidation of $[\mathrm{Fe} \text { (terpyridine)2 }]^{2+}$ complex (Supplementary Figures S5). As for UV-visible titrations, the voltammograms remain unchanged upon addition of more than 0.5 equiv of metal cation, confirming the formation of $\left[\mathrm{M}(\mathbf{5})_{2}\right]^{2+}$ complexes in all cases.

A new difunctional, simple ligand $\mathbf{5}$, composed of the pristine electron-donating TTF and the terpyridine coordinating units, has been synthesized in three steps from the commercially available TTF. The electronic absorption study demonstrates an intramolecular communication between the strong electron donor (TTF) and acceptor (terpy) parts which are directly connected. Transition metal titration experiments show that this model ligand is suitable for the preparation of electroactive metal complexes. The electrochemical behavior of the ligand indicates that the redox activity of TTF is preserved and suggests that $\mathbf{5}$ is also a useful candidate for the preparation of radical cation salts. Altogether, the easy-toprepare system $\mathbf{5}$ constitutes a model ligand suitable for a wide

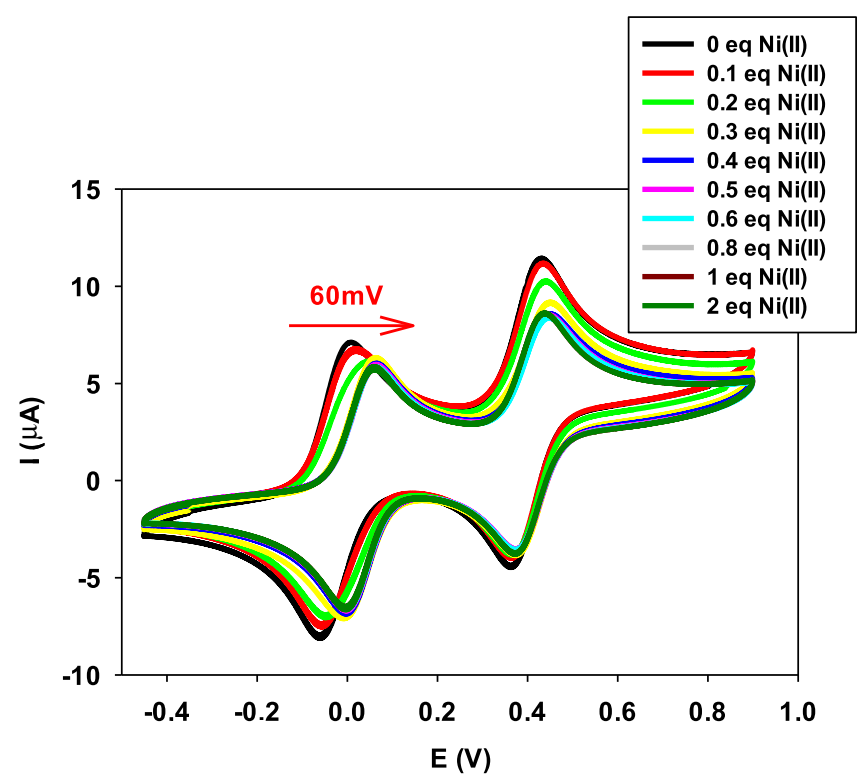

Figure 3. $\mathrm{CV}$ titration of $5\left(10^{-3} \mathrm{Mol} . \mathrm{L}^{-1}\right)$ in the presence of $\mathrm{Ni}\left(\mathrm{ClO}_{4}\right)_{2}, \mathrm{CH}_{2} \mathrm{Cl}_{2} /$ $\mathrm{CH}_{3} \mathrm{CN}(1 / 1), v=100 \mathrm{mVS}^{-1} \mathrm{Bu}_{4} \mathrm{NPF}_{6}\left(10^{-1} \mathrm{~mol} . \mathrm{L}^{-1}\right) / \mathrm{Fc}^{+} / \mathrm{Fc}$. range of applications, in particular indebted with the preparation of multifunctional molecular materials which exhibit a synergic interaction between a redox process and an alternative physical effect promoted by the bound metal (i.e., related to optics, magnetism, or conductivity).

\section{Acknowledgments}

The CMEP PHC Tassili (99 MDU 431) program is greatly acknowledged. Prof. Leriche is acknowledged for his help regarding calculations.

\section{Supplementary data}

Supplementary data (material contains UV-vis and CV spectra related to metal cations titrations) associated with this article can be found, in the online version, at http://dx.doi.org/10.1016/ j.tetlet.2013.03.102.

\section{References and notes}

1. Bendikov, M.; Wuld, F.; Perepichka, D. F. Chem. Rev. 2004, 104, 4891-4946. References therein.

2. (a) Bryce, M. R. J. Mater. Chem. 2000, 10, 589-598; (b) Segura, J. L.; Martín, N. Angew. Chem. Int. Ed. 2001, 40, 372-1409; (c) Yamada, J.: Sugimoto, T. TTF Chemistry: Fundamentals \& Applications of Tetrathiafulvalene; Kodansha (Tokyo) and Springer: Heidelberg, New York, Berlin, 2004.

3. For reviews, see (a) Canevet, D.; Salle, M.; Zhang, G. X.; Zhang, D. O.; Zhu, D. B. Chem. Commun. 2009, 2245-2269; (b) Nielsen, M. B.; Lomholt, C.; Becher, J. Chem. Soc. Rev. 2000, 29, 153-164; (c) Coskun, A.; Spruell, J. M.; Barin, G.; Dichtel, W. R.; Flood, A. H.; Botrosghi, Y. Y.; Stoddart, J. F. Chem. Soc. Rev. 2012, 41, 4827-4859.

4. (a) Coronado, E.; Galan-Marcos, J. R.; Gomez-Garcia, C. J.; Laukhin, V. Nature 2000, 408, 447-449; (b) Coronado, E.; Day, P. Chem. Rev. 2004, 104, 5419-5448; (c) Nihei, M.; Takahashi, N.; Nishikawa, H.; Oshio, H. J. Chem. Soc., Dalton Trans. 2011, 40, 2154-2156.

5. (a) Lorcy, D.; Bellec, N.; Fourmigué, M.; Avarvari, N. Coord. Chem. Rev. 2009, 253, 1398-1438; (b) Shatruk, M.; Ray, L. J. Chem. Soc., Dalton Trans. 2010, 39, 1110511121.

6. (a) Setifi, F.; Ouahab, L.; Golhen, S.; Yoshida, Y.; Saito, G. Inorg. Chem. 2003, 42, 1791-1793; (b) Liu, S.-X.; Dolder, S.; Franz, P.; Neels, A.; Stoeckli-Evans, H.; Decurtins, S. Inorg. Chem. 2003, 42, 4801-4803; (c) Devic, T.; Avarvari, N.; Batail, P. Chem. Eur. J. 2004, 10, 3697-3707; (d) Balandier, J.-Y.; Chas, M.; Goeb, S.; Dron, P. I.; Rondeau, D.; Belyasmine, A.; Gallego, N.; Sallé, M. New J. Chem. 2011, 35, 165-168; (e) Gavrilenko, K. S.; Le Gal, Y.; Cador, O.; Golhen, S.; Ouahab, L. Chem. Commun. 2007, 280-282; (f) Geng, Y.; Wang, X.-J.; Chen, B.; Xue, H.; Zhao, Y.-P.; Lee, S.; Tung, C.-H.; Wu, L.-Z. Chem. Eur. J. 2009, 15, 51245129; (g) Kolotilov, S. V.; Cador, O.; Pointillart, F.; Golhen, S.; Le Gal, Y.; Gavrilenko, K. S.; Ouahab, L. J. Mater. Chem. 2010, 20, 9505-9514; (h) Liu, S.-X.; Ambrus, C.; Dolder, S.; Neels, A.; Decurtins, S. Inorg. Chem. 2006, 45, 96229624; (i) Devic, T.; Batail, P.; Avarvari, N. Chem. Commun. 2004, 1538-1539.

7. (a) Devic, T.; Rondeau, D.; Şahin, Y.; Levillain, E.; Clérac, R.; Batail, P.; Avarvari, N. J. Chem. Soc., Dalton Trans. 2006, 1331-1337; (b) Hervé, K.; Liu, S.-X.; Cador, O.; Golhen, S.; Le Gal, Y.; Bousseksou, A.; Stoeckli-Evans, H.; Decurtins, S.; Ouahab, L. Eur. J. Inorg. Chem. 2006, 3498-3502; (c) Campagna, S.; Serroni, S.; Puntoriero, F.; Loiseau, F.; De Cola, L.; Kleverlaan, C. J.; Becher, J.; Sørensen, A. P.; Hascoat, P.; Thorup, N. Chem. Eur. J. 2002, 8, 446-4469.

8. (a) Bang, K. S.; Nielsen, M. B.; Zubarev, R.; Becher, J. Chem. Commun. 2000, 215216; (b) Keniley, L. K., Jr; Ray, L.; Kovnir, K.; Dellinger, L. A.; Hoyt, J. M.; Shatruk, M. Inorg. Chem. 2010, 49, 1307-1309; (c) Dupont, N.; Ran, Y.-F.; Jia, H.-P.; Grilj, J.; Ding, J.; Liu, S.-X.; Decurtins, S.; Hauser, A. Inorg. Chem. 2011, 50, 3295-3303.

9. (a) Chahma, M.; Hassan, N.; Alberola, A.; Stoeckli-Evans, H.; Pilkington, M. Inorg. Chem. 2007, 46, 3807-3809; (b) Qin, J.; Qian, C.-X.; Zhou, N.; Zhu, R.-M.; Li, Y.-Z.; Zuo, J.-L.; You, X.-Z. Eur. J. Inorg. Chem. 2012, 234-245; (c) Nita, G.; Branzea, D.; Pop, F.; El-Ghayoury, A.; Avarvari, N. Crystals 2012, 2, 338-348; (d) Wu, J.-C.; Liu, S.-X.; Keene, T. D.; Neels, A.; Mereacre, V.; Powell, A. K.; Decurtins, S. Inorg. Chem. 2008, 47, 3452-3459.

10. Branzea, D. G.; Fihey, A.; Cauchy, T.; El-Ghayoury, A.; Avarvari, N. Inorg. Chem. 2012, 51, 8545-8556.

11. (a) Cargill Thompson, A. M. W. Coord. Chem. Rev. 1997, 160, 1-52; (b) Schubert, U. S.; Hofmeier, H.; Newkome, G. R. Modern Terpyridine Chemistry; Wiley-VCH: Weinheim, 2006.

12. Wang, Q.; Day, P.; Griffiths, J.-P.; Nie, H.; Wallis, J. D. New J. Chem. 2006, 30, $1790-1800$.

13. (a) Iliopoulos, K.; El-Ghayoury, A.; El Ouazzani, H.; Pranaitis, M.; Belhadj, E.; Ripaud, E.; Mazari, M.; Sallé, M.; Gindre, D.; Sahraoui, B. Opt. Express 2012, 20 , 25311-25316; (b) Belhadj, E.; El-Ghayoury, A.; Ripaud, E.; Zorina, L.; Allain, M.; Batail, P.; Mazari, M.; Sallé, M. New J. Chem. 2013. http://dx.doi.org/10.1039/ C3NJ00041A. 
3054

E. Belhadj et al./Tetrahedron Letters 54 (2013) 3051-3054

14. Hildebrandt, A.; Wetzold, N.; Ecorchard, P.; Walfort, B.; Rüffer, T.; Lang, H. Eur. J. Inorg. Chem. 2010, 3615-3627.

15. Garín, J.; Orduna, J.; Uriel, S.; Moore, A. J.; Bryce, M. R.; Wengener, S.; Yufit, D. S.; Howard, J. A. K. Synthesis 1993, 489-493.

16. At $30^{\circ} \mathrm{C}$ and under argon, an excess of sodium methanolate $(0.1 \mathrm{~g}, 1.9 \mathrm{mmol})$ is added to a solution of 2-acetylpyridine $(0.11 \mathrm{~mL}, 0.95 \mathrm{mmol})$ in anhydrous THF $(10 \mathrm{~mL})$. The solution turns purple and after $40 \mathrm{~min}$ stirring, a solution of tetrathiafulvalenecarboxaldehyde $1(0.1 \mathrm{~g}, 0.43 \mathrm{mmol})$ in anhydrous THF $(5 \mathrm{~mL})$ was added. The reaction mixture was stirred for $12 \mathrm{~h}$. After filtration and solvent evaporation, the resulting residue was dissolved in a minimum of dichloromethane and chromatographed through a silica gel column chromatography using dichloromethane/hexane: $9 / 1 \mathrm{v} / \mathrm{v}$ as the eluent. The resulting TTF-enone 3 was obtained as a blue solid in $30 \%$ yield. $\delta_{\mathrm{H}}(300 \mathrm{MHz}$, $\left.\mathrm{CDCl}_{3}\right), 8.78(\mathrm{~m}, 1 \mathrm{H}, \mathrm{CH}=\mathrm{N}$ Pyr $), 8.17(\mathrm{~m}, 1 \mathrm{H}, \mathrm{CH}=\mathrm{Pyr}), 7.88(\mathrm{~m}, 1 \mathrm{H}, \mathrm{CH}=\mathrm{Py})$, 7.49-7.67 (m, 3H, $\mathrm{CH}=$ Pyr \& $\mathrm{CH}=\mathrm{CH}-\mathrm{CO}), 6.90$ (s, 1H, CH=C, TTF), 6.38 (dd, $2 \mathrm{H}, \mathrm{CH}=\mathrm{CH}, \mathrm{TTF}) . \delta \mathrm{C}\left(75 \mathrm{MHz}, \mathrm{CDCl}_{3}\right), 189.0(\mathrm{C}=\mathrm{O}), 153.8(\mathrm{CH}=\mathrm{CH}, \mathrm{Pyr}), 149.0$ $(\mathrm{CH}=\mathrm{CH}, \mathrm{Pyr}), 137.0(\mathrm{CH}=\mathrm{CH}, \mathrm{Pyr}), 135.8(\mathrm{CH}=\mathrm{CH}, \mathrm{TTF}), 134.1(\mathrm{CH}=\mathrm{CH}, \mathrm{TTF})$, $129.4(\mathrm{CO}-\mathrm{CH}=\mathrm{CH}), 127.0(\mathrm{CH}=\mathrm{CH}, \mathrm{Pyr}), 123.0(\mathrm{CH}=\mathrm{CH}, \mathrm{Pyr}), 122.8(\mathrm{CO}-$ $\mathrm{CH}=\mathrm{CH}), 118.9-119.2(\mathrm{CH}=\mathrm{CH}, \mathrm{TTF}), 114.3(\mathrm{CH}=\mathrm{CH}, \mathrm{TTF}), 107.6(\mathrm{CH}=\mathrm{CH}, \mathrm{TTF})$. MALDI-TOF MS calcd: $m / z=334.9$ Da. found: $m / z 335.1[\mathrm{M}]^{+}$.

17. Priimov, G. U.; Moore, P.; Maritim, P. K.; Butalanyi, P. K.; Alcock, N. W. J. Chem. Soc., Dalton Trans. 2000, 445-449.

18. A mixture of enone-TTF $3(0.200 \mathrm{~g}, 0.590 \mathrm{mmol})$ and pyridinium iodide 4 $(0.231 \mathrm{~g}, 0.700 \mathrm{mmol})$, in the presence of an excess of ammonium acetate $(0.525 \mathrm{~g}, 6.600 \mathrm{mmol})$ is refluxed in anhydrous ethanol $(4 \mathrm{~mL})$, under argon, during $3 \mathrm{~h}$. After cooling down to room temperature, the resulting precipitate was filtered off and washed with cold ethanol. The precipitated was then dissolved in dichloromethane and chromatographed on a $\mathrm{NEt}_{3}$ pretreated silica gel using dichloromethane as the eluent. The TTF-terpy ligand 5 was obtained in $20 \%$ yield. $M p 138^{\circ} \mathrm{C} ; \delta \mathrm{H}\left(300 \mathrm{MHz}, \mathrm{CDCl}_{3}\right), 8.75(\mathrm{~m}, 2 \mathrm{H}, \mathrm{Terpy}), 8.65(\mathrm{~m}, 2 \mathrm{H}$, Terpy), 8.48 (s, 2H, Terpy), 7.90 ( $\mathrm{m}, 2 \mathrm{H}, \mathrm{Terpy}), 7.39$ ( $\mathrm{m}, 2 \mathrm{H}, \mathrm{Terpy}), 7.17$ (s, $1 \mathrm{H}$, TTF), 6.39 (dd, $J=6.5 \mathrm{~Hz}, J=1.2 \mathrm{~Hz}, 2 \mathrm{H}, \mathrm{TTF}): \delta \mathrm{C}\left(75 \mathrm{MHz}, \mathrm{CDCl}_{3}\right), 156.1(\mathrm{C}=\mathrm{N})$, $155.7(\mathrm{C}=\mathrm{N}), 149.2(\mathrm{C}=\mathrm{N}), 141.1(\mathrm{C}=\mathrm{N}), 136.9(\mathrm{C}=\mathrm{C}), 134.4(\mathrm{C}=\mathrm{C}), 124.1$ $(C=C), 121.4(C=C), 119.0(C=C), 118.9(C=C), 117.4(C=C), 112.7(C=C), 108.1$ $(\mathrm{C}=\mathrm{C})$. MALDI-TOF MS calcd: $m / z=435.0 \mathrm{Da}$. found: $\mathrm{m} / z$ 434.8 [M] ${ }^{+}$. HR-MS (M): for $\mathrm{C}_{21} \mathrm{H}_{13} \mathrm{~N}_{3} \mathrm{~S}_{4}$ : 434.9992. found 435.0001.

19. Andreu, R.; Malfant, I.; Lacroix, P. G.; Cassoux, P. Eur. J. Org. Chem. 2000, 737741.

20. Frisch, M.J.; Trucks, G.W.; Schlegel, H.B.; Scuseria, G.E.; Robb, M.A.; Cheeseman, J.R.; Montgomery, Jr. J.A.; Vreven, T.; Kudin, K.N.; Burant, J.C.; Millam, J.M.; Iyengar, S.S.; Tomasi, J.; Barone, V.; Mennucci, B.; Cossi, M.; Scalmani, G.; Rega, N.; Petersson, G.A.; Nakatsuji, H.; Hada, M.; Ehara, M.; Toyota, K.; Fukuda, R.; Hasegawa, J.; Ishida, M.; Nakajima, T.; Honda, Y.; Kitao, O.; Nakai, H.; Klene, M.; Li, X.; Knox, J.E.; Hratchian, H.P.; Cross, J. B.; Adamo, C.; Jaramillo, J.; Gomperts, R.; Stratmann, R.E.; Yazyev, O.; Austin, A.J.; Cammi, R.; Pomelli, C.; Ochterski, J.W.; Ayala, P.Y.; Morokuma, K.; Voth, G.A.; Salvador, P.; Dannenberg, J.J.; Zakrzewski, V.G.; Dapprich, S.; Daniels, A.D.; Strain, M.C.; Farkas, O.; Malick, D.K.; Rabuck, A.D.; Raghavachari, K.; Foresman, J.B.; Ortiz, J.V.; Cui, Q.; Baboul, A. G.; Clifford, S.; Cioslowski, J.; Stefanov, B. B.; Liu, G.; Liashenko, A.; Piskorz, P.; Komaromi, I.; Martin, R.L.; Fox, D.J.; Keith, T.; Al-Laham, M.A.; Peng, C.Y.; Nanayakkara, A.; Challacombe, M.; Gill, P.M.W.; Johnson, B.; Chen, W.; Wong, M.W.; Gonzalez, C.; Pople, J. A. Gaussian03, Revision B.04, Gaussian, Pittsburgh, PA, 2003.

21. Braterman, P. S.; Song, J.-I.; Peacock, R. D. Inorg. Chem. 1992, 31, 555-559.

22. Balandier, J. Y.; Belyasmine, A.; Sallé, M. Eur. J. Org. Chem. 2008, 269-276. 